\title{
Forecasting the behaviour of complex landslides with a spatially distributed hydrological model
}

\author{
J.-P. Malet ${ }^{1,2}$, Th. W. J. van Asch ${ }^{1}$, R. van Beek ${ }^{1}$, and O. Maquaire ${ }^{2,3}$ \\ ${ }^{1}$ Faculty of Geosciences, UCEL, P.O. Box 80115, 3508 TC Utrecht, The Netherlands \\ ${ }^{2}$ Institute of Global Physics, School and Observatory of Earth Sciences, UMR 7516 ULP-CNRS, 5, rue Descartes, F-67084 \\ Strasbourg Cedex, France \\ ${ }^{3}$ Géographie Physique et Environnement, LETG-Geophen, UMR 6554 CNRS, Esplanade de la Paix, BP 5186, F-14032 Caen \\ Cedex, France
}

Received: 31 March 2004 - Revised: 19 November 2004 - Accepted: 13 December 2004 - Published: 6 January 2005

Part of Special Issue "Monitoring and modeling of landslides and debris flows"

\begin{abstract}
The relationships between rainfall, hydrology and landslide movement are often difficult to establish. In this context, ground-water flow analyses and dynamic modelling can help to clarify these complex relations, simulate the landslide hydrological behaviour in real or hypothetical situations, and help to forecast future scenarios based on environmental change. The primary objective of this study is to investigate the possibility of including more temporal and spatial information in landslide hydrology forecasting, by using a physically based spatially distributed model. Results of the hydrological and geomorphological investigation of the Super-Sauze earthflow, one of the persistently active landslide occurring in clay-rich material of the French Alps, are presented. Field surveys, continuous monitoring and interpretation of the data have shown that, in such material, the groundwater level fluctuates on a seasonal time scale, with a strong influence of the unsaturated zone. Therefore a coupled unsaturated/saturated model, incorporating Darcian saturated flow, fissure flow and meltwater flow is needed to adequately represent the landslide hydrology. The conceptual model is implemented in a 2.5-D spatially distributed hydrological model. The model is calibrated and validated on a multi-parameters database acquired on the site since 1997. The complex time-dependent and three-dimensional groundwater regime is well described, in both the short- and longterm. The hydrological model is used to forecast the future hydrological behaviour of the earthflow in response to potential environmental changes.
\end{abstract}

Correspondence to: J.-P. Malet

(j.malet@geog.uu.nl)

\section{Introduction}

- What changes can be expected in the activity of large landslides in the future under the impact of environmental changes?

- What are the most active processes governing the recharge of a landslide groundwater table and the thresholds triggering an acceleration in displacement?

Geoscientists are often called upon to predict the behaviour of landslide complexes by answering questions like these assuming that the majority of the landslide triggering mechanisms is related to hydrological triggering, induced by rainfall or snowmelt (Iverson and Major, 1986; Iverson, 2000; Montgomery and Dietrich, 1994; Ng and Shi, 1998; Cappa et al., 2004). Indeed, because of the large variability in the quantity of water stored in the saturated and unsaturated zones and the comparatively few return periods of critical rainy episodes, the behaviour of many landslides seems to be mainly governed by the hydrological system (Hodge and Freeze, 1977; Haneberg, 1991; Iverson, 1992). This implies that it is important to describe the saturated and non-saturated fluxes and to study the influence of macropores and fissures on landslide activity (Keefer and Johnson, 1983; van Asch et al., 1999).

Although some decisions can be made using best engineering or best geologic judgment, in many instance these approaches are inadequate to analyse complex landslide groundwater systems. A better tool to help geoscientists meet the challenge of forecasting is usually a hydrological model describing the relations between climate characteristics (inputs) and groundwater responses (outputs). Surprisingly, modelling the hydrological factors which control 

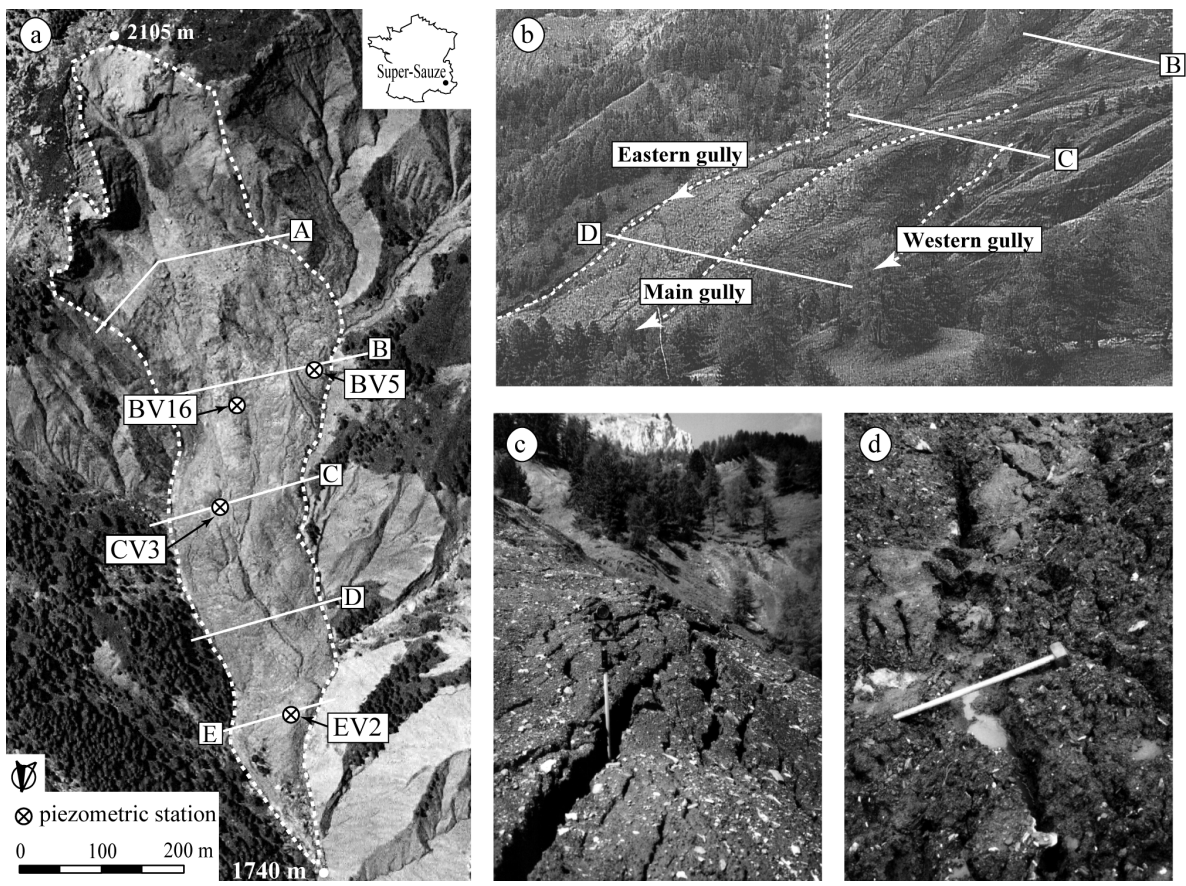

Fig. 1. Morphological sketch of the Super-Sauze earthflow. (a) Aerial ortho-photographs of the earthflow. The letters A to E refer to the investigated cross-sections. (b) Morphological track of the earthflow and location of the drainage streams. (c), (d) Dry (August 2000) and saturated tension cracks (May 2001) in the upper part of the earthflow.

landslides has been slow to gain acceptance (Anderson and Kemp, 1988; Brunsden, 1999), compared to watershed hydrological modelling or rainfall-runoff modelling. Nevertheless, this aspect has been gaining ground in recent years as geotechnical, geomorphological and hydrological models are drawn closer together (Corominas, 1998). The research challenges involve the complexity of real landslides, the difficulty of surveying piezometric levels in "moving environments", the difficulty at understanding the water pathways within complex landslide bodies, and the inability of hydrological models to handle large complex systems with 3-D effects (Ambroise, 1999; Brunsden, 1999; Ridolfi et al., 2003).

In the last decade, the growth of distributed databases (rainfall, temperature, capillary pressure head, soil moisture content, groundwater level) on several landslides (La Clapière, Séchilienne in France; Tessina, Corvara, Alvéra in Italy; Vallcebre in Spain, and others) has allowed the development and the validation of both lumped and physically based hydrological models. Therefore, the primary objective of this study is to demonstrate the potential of dynamic distributed models in forecasting landslide hydrology.

Results of a detailed hydrological investigation of the Super-Sauze earthflow, one of the persistently active landslide occurring in clay-rich material of the French Alps (Malet and Maquaire, 2003), are presented. The earthflow moves significant distances each rainy season: however, the timing, duration, and speed of movement do not correlate directly with the timing and amount of rainfall (Malet et al., 2002). The unsaturated zone strongly attenuates and delays the precipitation. Moreover snowmelt water and preferential fissure flows have a considerable influence on recharge of the groundwater table. Therefore a coupled unsaturated/saturated model is needed for landslides occurring in this material. A concept for the temporal behaviour of these landslides is proposed and implemented in a distributed physically based hydrological model. The model is calibrated and validated at the field scale. Two practical applications of the model for hazard assessment and risk management are then presented.

\section{Landslide hydrology: modelling strategy}

There are almost as many different hydrological models as there are listed types of landslides, so it is essential to identify clearly the purpose of the modelling effort at the onset of the study, and to establish a modelling strategy.

Although most earlier research has focussed on the hydrological behaviour of shallow landslides typically controlled by the travel time of the precipitation input through the unsaturated zone (van Beek and van Asch, 1999; Brooks et al., 2002), or on the mechanics of deep-seated landslides controlled by saturated conditions (Cappa et al., 2003), less research has focused on the landslides governed by both saturated and unsaturated conditions. Moreover, the traditional modelling approach involves an overall representation by area-average values of equivalent parameters. Numerical codes can be more or less complex, from simple 1-D lumped models to complex physically based 2-D or 3-D models for saturated and unsaturated flows (Corominas, 1998). Dis- 


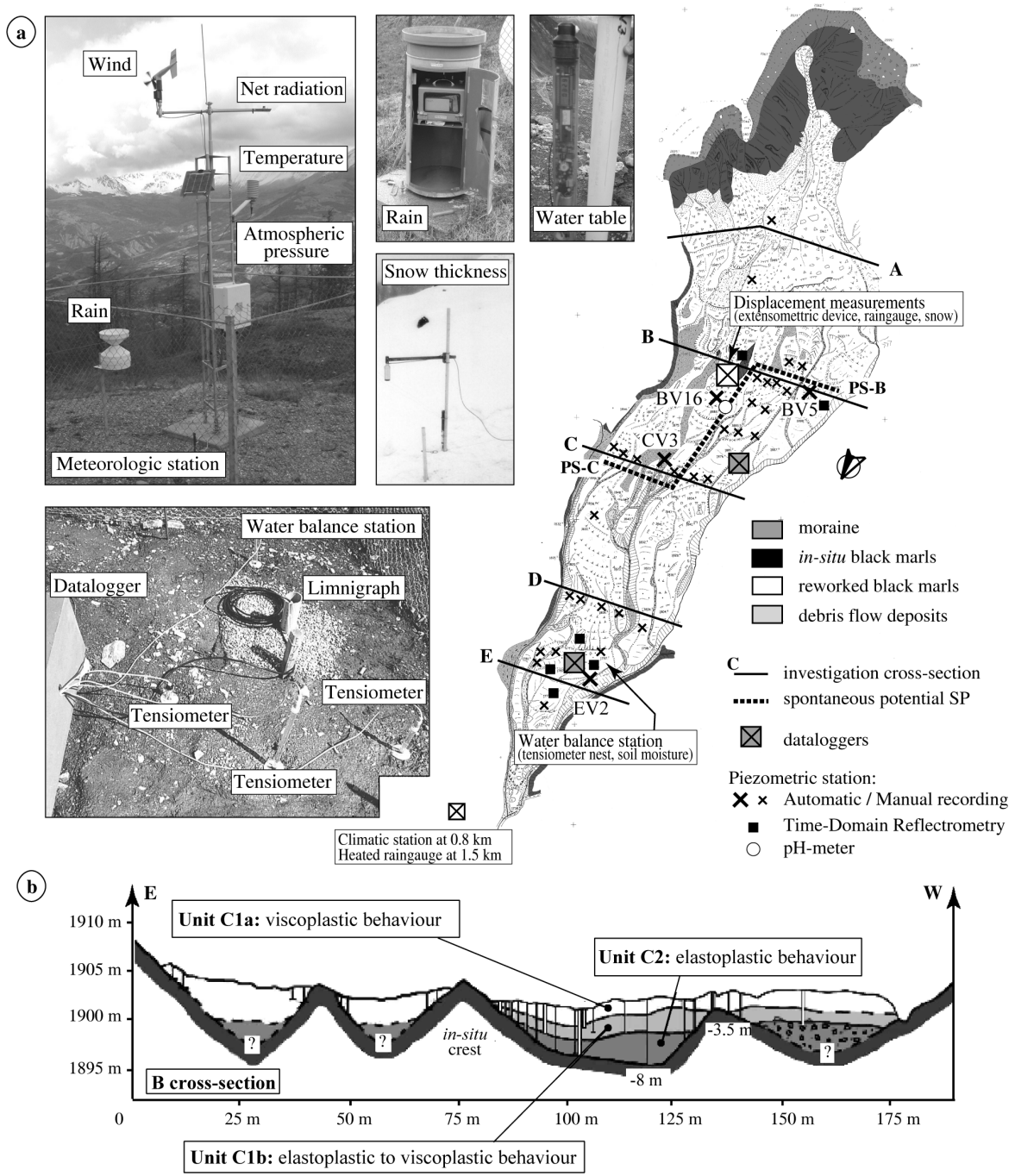

Fig. 2. (a) Hydrological instrumentation of the Super-Sauze earthflow. (b) Geotechnical structure of the earthflow in its upper part (B crosssection).

tributed approaches, either 2-D or 3-D, are valuable because they can account for the spatial variability of the landslide material, for the topographic control on the convergence of flows, or for the division of the hydrological system into hydro-geomorphological units (Reid et al., 1988; Miller and Sias, 1998).

Our research attempts to validate a distributed physically based hydrological code for complex landslides affecting fine-grained material, characterized by saturated and unsaturated conditions. The modelling strategy includes concept definition, code formulation, sensitivity analysis, model validation, and finally forecasting (Anderson and Woessner, 1991). In particular, the definition of a conceptual model of the landslide system is of paramount importance because different types of landslides have different hydrological systems and react at different temporal scales to the precipitation input (van Asch et al., 1999).

\section{Field setting and data collection}

\subsection{Morphological and geological context}

Deep-seated earthflows are the most typical landslides involving black marls in the Southeastern part of the French Alps (Maquaire et al., 2003). They are generally the result of catastrophic failures in which an initial structural rock block slide transforms into a slow-moving massive translational landslide progressing down stream channels. Their movements, influenced by slope morphology, rock-mass fabric, and hydrology, may result from sliding and flowing either singly or in combination (Malet and Maquaire, 2003).

About $100 \mathrm{~km}$ north of Nice, four large earthflows (Poche, Super-Sauze, La Valette and Dourbes) are very active and exhibit similar morphologies. Among these earthflows, the Super-Sauze earthflow (Fig. 1) has been surveyed by the School and Observatory of Earth Sciences (Strasbourg, France) since 1991 (Flageollet et al., 2004). The earthflow 

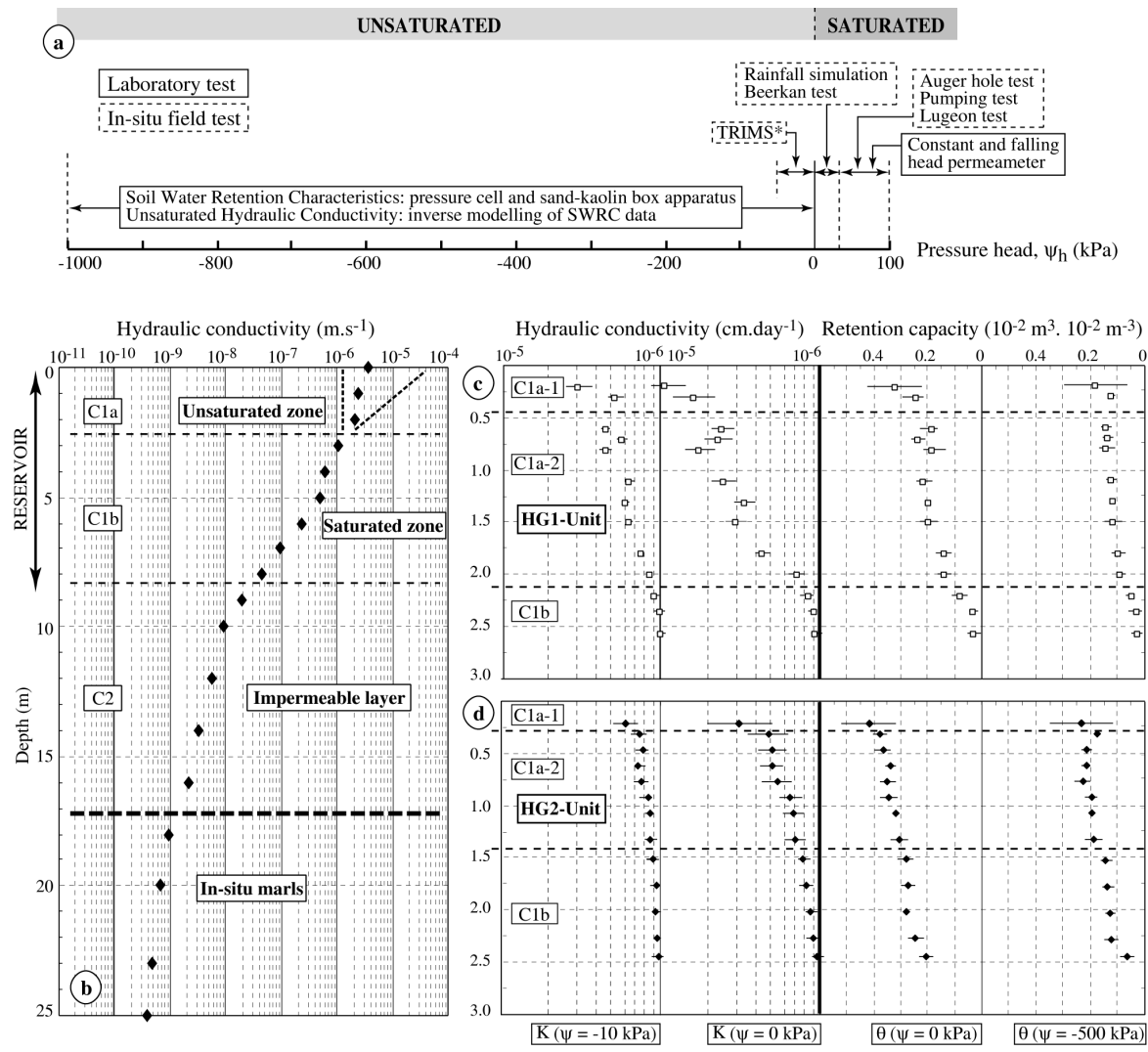

Fig. 3. Hydrodynamical properties of the earthflow. (a) Hydrological tests performed to study the hydrodynamical behaviour of the material in both unsaturated and saturated conditions. (b) Variation of hydraulic conductivity in depth in the mid-part of the earthflow (C crosssection). (c), (d) Variation of hydraulic conductivity and retention capacity in the unsaturated zone with special reference to the hydrogeomorphological units HG1 and HG2 (see Sect. 3.3.3 for the description of these units).

extents over an horizontal distance of $820 \mathrm{~m}$ and occurs between an elevation of $2105 \mathrm{~m}$ (crown) and $1740 \mathrm{~m}$ (toe) with an average $25^{\circ}$ slope. It has a flow-like tongue morphology (Fig. 1a). A detailed morphological description of the earthflow since its genesis in the mid-seventies can be found in Weber and Herrmann (2000). The paleotopography, a succession of more or less parallel crests and gullies, plays an essential role in the behaviour of the flow by delimiting preferential water and material pathways and creating sections with differing kinematical, mechanical and hydrological characteristics. The total volume is estimated at $750000 \mathrm{~m}^{3}$ and velocities range from 0.01 to $0.4 \mathrm{~m} \cdot \mathrm{day}^{-1}$. The earthflow is bordered by two lateral gullies with perennial run-off (Fig. 1b) and characterized by a central intraflowing gully with intermittent run-off (Fig. 1b). Water flows in the gullies and in the landslide varie greatly with the season, as can be observed by the presence of dry or saturated cracks (Figs. 1c, 1d).

Malet et al. (2002) have demonstrated that rainfall is the main triggering factor of the earthflow motion, and it produces an intermittent and delayed recharge of the groundwater. The earthflow has been active since 1970's. The longterm kinematics are characterized by continuous movements with a seasonal trend. Its continued motion is likely given a
Factor of Safety that is often below unity (Maquaire et al., 2003).

3.2 Geometry and internal geotechnical structure of the earthflow

Observations and on-site measurements of the meteorological characteristics, the hydrology and displacements at the earthflow began in 1991 (Flageollet et al., 2004). A geophysical and geotechnical investigation combined with a photogrammetric analysis was initiated in 1996 along five cross-sections in order to determine the structure of the accumulated mass (Schmutz et al., 2000). A water balance station to monitor pressure heads, combined with several Time-Domain-Reflectrometry sensors to monitor soil moisture over depth, has been installed in 1997. Around thirty open standpipe piezometers with manual recordings, filtered at different levels, were installed on five cross-sections to define the geometry of the water reservoir. Among them, four piezometric recorders were installed to monitor pore pressure (Fig. 2a). Cross-correlation of all information in a distributed database has allowed the construction of a hydrological and mechanical concept of the earthflow (Malet, 2003).

The earthflow consists of a heterogeneous tongue with a 
high silty-sand matrix mixed with morainic debris. Its vertical structure consists of two superimposed units (Maquaire et al., 2001). The upper unit, 5 to $9 \mathrm{~m}$ thick, is a very wet viscous muddy formation, which can be sub-divided into two sub-units ( $\mathrm{Cla}$ and $\mathrm{C} 1 \mathrm{~b})$ depending on the shape of the paleotopography. This unit is very active from a hydrological and mechanical view point. The lower unit, with a maximum thickness of $10 \mathrm{~m}$, is a stiff compact, relatively impervious and apparently stable formation (Malet et al., 2002).

\subsection{Hydrological behaviour of the earthflow}

In the following, the hydroclimatic time series (precipitation, either liquid or solid, temperature, net radiation, soil water content, soil suction, pressure head, groundwater level) over the period 1997-2001 and the results of an extended hydrological investigation are used to define a hydrological concept.

\subsubsection{Reservoir geometry and hydrodynamical parameters}

The geometry of the hydrological system is identified by two static surfaces, the ground surface and the bottom of the reservoir, and a dynamic one, the water table. The reservoir consists of $\mathrm{C} 1 \mathrm{a}$ et $\mathrm{C} 1 \mathrm{~b}$ units. The eastward and westward streams are considered as lateral boundaries of the landslide system (Fig. 1b). The thickness of the reservoir averages $7-8 \mathrm{~m}$ on cross-sections $\mathrm{A}$ and $\mathrm{C}$, and $4 \mathrm{~m}$ on crosssections $\mathrm{B}, \mathrm{D}$ and $\mathrm{E}$. The total volume of the reservoir is estimated at $300000 \mathrm{~m}^{3}$. Subsurface water heights between -0.5 and $-1.5 \mathrm{~m}$ were observed in the upstream section of the earthflow (cross-sections A, B, C), while deeper water levels $(-2.5 \mathrm{~m}$ to $-3.5 \mathrm{~m})$ are observed in the western parts of cross-sections B and C. Moreover, the depth of the highest position of the groundwater table slowly decreases from the B cross-section $(-0.20 \mathrm{~m})$ to the $\mathrm{E}$ cross-section $(-0.80 \mathrm{~m})$. In the unsaturated zone, the volumetric water content varies considerably, ranging from 0.08 to 0.35 .

Hydraulic conductivities were extensively tested both in laboratory and in-situ (Fig. 3a). Permeability variation with depth has been estimated by some sixty auger hole tests in the reworked marls and four Lugeon tests in the in-situ marls (Fig. 3b). In the unsaturated zone, vertical hydraulic conductivities were estimated in-situ by tension disk infiltrometry for pressures heads of $-0.1 \mathrm{~m}$ and at saturation (Fig. 3c). To estimate the horizontal conductivity $K_{H}$, soil samples were taken horizontally at different depths, following the methodology proposed by Caris and van Asch (1991). The matric suction-moisture content relationship was obtained through a sand and kaolin box apparatus for pressure heads between $\mathrm{pF} 1.0$ and $\mathrm{pF}$ 2.7, and with a suction plate membrane apparatus for $\mathrm{pF} 3.6$ and $\mathrm{pF}$ 4.2. The maximum water storage was derived from the $\mathrm{pF}$ curves on more than 250 samples (Malet, 2003).

The observed hydrological behaviour is in accordance with the silty-sand texture of the material. The observed range of hydraulic conductivity values (Figs. 3b, 3c) classi- fies the material as semi-permeable (De Marsily, 1986). The auger hole tests show a decrease in permeability with depth (Fig. 3b), connected to the increasing compaction of the materials, with values of up to $10^{-5} \mathrm{~m} \cdot \mathrm{s}^{-1}$ between $-1 \mathrm{~m}$ and $-2 \mathrm{~m}$, up to $10^{-8} \mathrm{~m} \cdot \mathrm{s}^{-1}$ in the lower unit. Furthermore the Lugeon test carried out in-situ indicates a permeability of $10^{-10} \mathrm{~m} \cdot \mathrm{s}^{-1}$. For the purposes of our modelling study, this allows us to assume the lower unit of the earthflow and the underlying in-situ intact material as impermeable.

In the unsaturated zone, the hydraulic conductivity values vary greatly according to the soil surface characteristics (Malet et al., 2003) and the presence of fissures from $10^{-4} \mathrm{~m} . \mathrm{s}^{-1}$ to $10^{-8} \mathrm{~m} . \mathrm{s}^{-1}$ (Figs. 3c, 3d). The retention values range between 0.17 and $0.42 .10^{-2} \mathrm{~m}^{3} \cdot 10^{-2} \mathrm{~m}^{-3}$. The matric suction-moisture content relationship is well represented by a simple Farrel and Larson model (1972). The parametric values of this model agree with those described in the literature for black marl soils (Caris and van Asch, 1991; Antoine et al., 1995; van Asch and Buma, 1997).

The average transmissivity of the entire reservoir, calculated with the analytical solution of Théis and the logarithmic approximation of Jacobs (Théis, 1941; Freeze and Cherry, 1979), on the basis of twenty one groundwater rises observed in piezometers BV16 and EV2, is as high as $10^{-5} \mathrm{~m}^{2} \cdot \mathrm{s}^{-1}$. Consequently, the storage coefficient (i.e. effective porosity) of the reservoir, is very low $(0.21 \pm 0.04)$. The effective porosity estimated with the Théis equation (15\%) was confirmed by mercury porosimetry measurements which indicated a kinematic porosity from 17 to $23 \%$ (Schmutz et al., 2000).

\subsubsection{Mass balance factors of the hydrological system}

Inputs (rainfall, snowfall) and outputs (surface water, evaporation) of the saturated zone represent the mass balance of the hydrological system. The long-term yearly cumulated precipitation is usually 750 to $900 \mathrm{~mm}$ (with about 200 to $250 \mathrm{~mm}$ as snowfall), but the maximum daily or monthly value can vary greatly and produce significant groundwater fluctuations (Malet, 2003). A monthly value of 150 to $200 \mathrm{~mm}$ can occur especially in April, May, October or November. Three rain gauges installed in a 5-square kilometre area around the landslide allowed us to quantify rainfall variability (Fig. 2a). A climatic station allowed us to estimate the reference potential evapotranspiration according to the Penman equation and it recorded Snow Water Equivalent. As snow is the main mode of precipitation during winter, a snow depth sensor was installed on the site at $2000 \mathrm{~m}$ a.s.l.

No springs are visible on the flanks of the earthflow. Surface water discharge was measured temporarily in the midstream section of the central gully of the landslide for several climatic conditions. During periods of medium and high rainfall, high peaks in stream discharge were observed, but no lag time with precipitation was measured. Unfortunately, the hydrograph could not be evaluated. More information is needed to quantitatively reproduce this aspect of the hydrological system. 

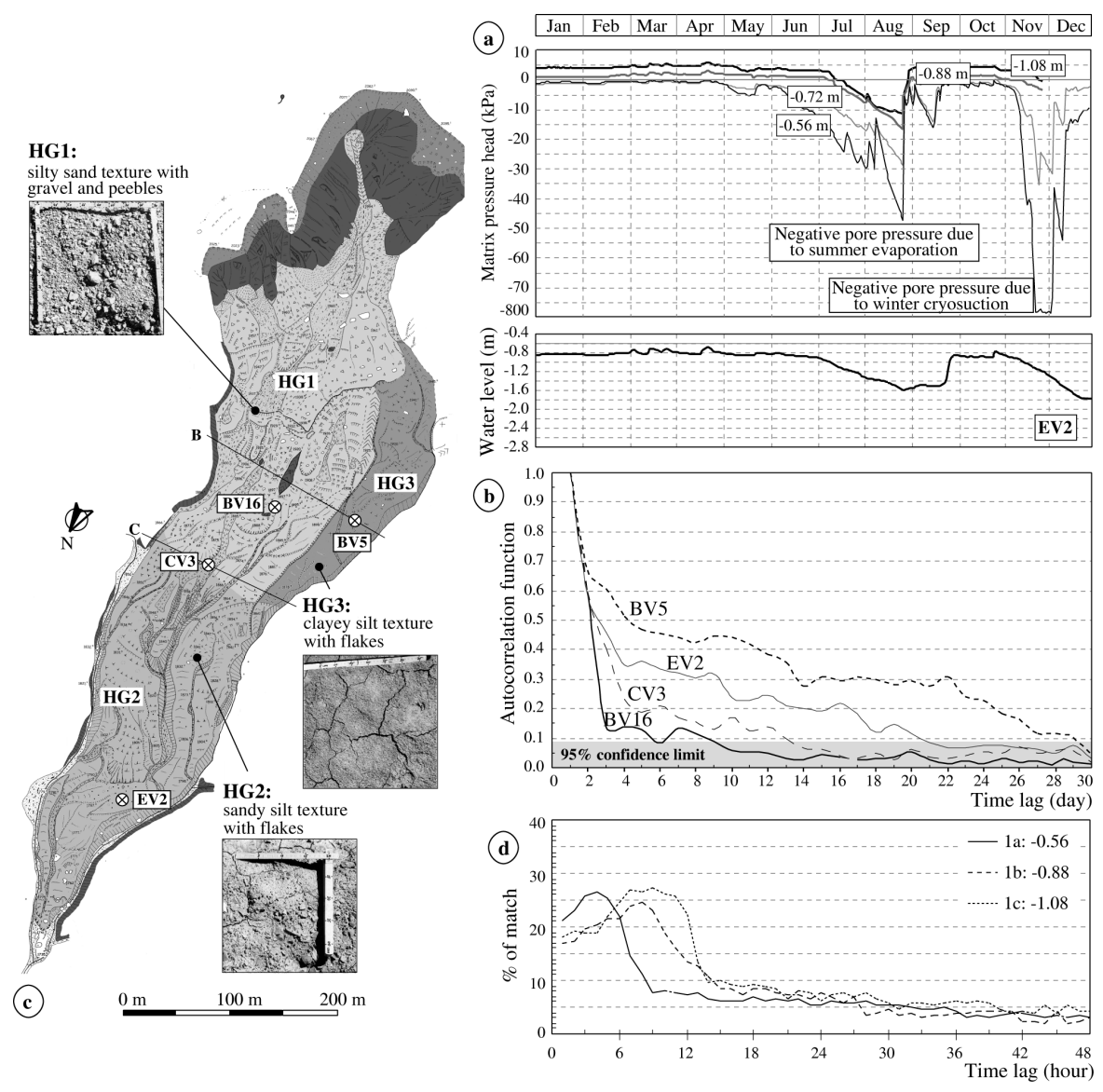

Fig. 4. Hydro-geomorphological units of the earthflow. (a) Example of matrix pressure heads and groundwater time series over the year 1998 in the lower part of the earthflow (piezometric station EV2). (b) Autocorrelation functions for groundwater level fluctuations of the four monitoring locations. (c) Boundaries of the hydro-geomorphological units and associated soil surface characteristics. (d) Cross-association results of matrix pressure heads fluctuations for three monitoring depths at site EV2.

\subsubsection{Qualitative inferences from field data: analysis of groundwater flow}

The earthflow is characterized by high groundwater levels whose fluctuations are correlated with rainfall and snowmelt. Figure 4a shows an example of the rainfall-groundwater table relations for the year 1998 in the lower part of the earthflow. The piezometric behaviour shows high pore pressure variations (up to $20-25 \mathrm{kPa}$ corresponding to an average fluctuation of the groundwater level of about $2.5 \mathrm{~m}$ ) with sudden recharge following snowmelt. Pore pressures may remain high for a long time due to the medium permeability of the reworked marls and the presence of the relatively impermeable layer underneath. Groundwater table fluctuations follow the same trend all over the earthflow, but the relative position of the water level depends on local conditions. Water level fluctuations of different intensity are related to changes in permeability and geometry of the earthflow.

For the purpose of this study, daily precipitation in relation to the daily groundwater fluctuations was analysed statistically (autocorrelation functions, cross-association and correlation techniques) on four automatic piezometric stations over the period 1999-2002, and on twenty one piezometric stations between June and October 1996 with daily manual recordings. Figure $4 \mathrm{~b}$ shows an example of the autocorrelation function of the groundwater level fluctuations (entire pore pressure record). The autocorrelation functions of BV5 and EV2 show a high autocorrelation value $(>0.3)$ for time lags up to 10 days. The fact that these piezometric stations have long gradual rising and falling stages helps explain this correlation. They also correspond to the less active part of the earthflow. CV3 and in particular BV16 show less much autocorrelation. These piezometric stations experience shortterm fluctuations and are more likely influenced by external factors (fissure density) than by system memory. Therefore, on the basis of geomorphological observations (grain size and soil surface characteristics (Fig. 4c), of soil hydrodynamical properties (hydraulic conductivity and retention capacity, Figs. 3c, 3d), and considering autocorrelation functions of CV3 and BV16 similar, three hydro-geomorphological units can be identified (Fig. 4c):

- the HG1 unit, exhibits very rapid piezometric responses $(<1 \mathrm{~h})$, a significant fluctuation (up to +0.4 to $0.5 \mathrm{~m}$ ) 
and rapid drainage (3-5 h);

- the HG2 unit, exhibits rapid piezometric responses (2$3 \mathrm{~h}$ ), a modest fluctuation ( +0.05 to $+0.3 \mathrm{~m})$ and relatively rapid drainage (12-24 h);

- the HG3 unit, exhibits slow piezometric responses $(>5 \mathrm{~h})$, low fluctuation (centimetric) and slow drainage $(>24 \mathrm{~h})$.

The infiltration in the unsaturated zone was studied in more detail through the analysis of the soil moisture variations, and the short-term variation of matrix pressure heads (Figs. 4a, 4d). These fluctuations are representative of the HG2 unit (Fig. 4c). On an annual basis, the range of matrix pressure heads varies between saturation and an average of $+150 \mathrm{kPa}$. For specific climatic situations, soil suction may reach more than $40 \mathrm{kPa}$ in summer, or even $80 \mathrm{kPa}$ when the soil freezes (Fig. 4a). Water is transported to depth quickly with an immediate drop in pressure potentials after rainfall. Moreover, in the top layer, saturation always remains temporary $(1 / 4 \mathrm{~h}$ to $2 \mathrm{~h}$ ) after a rainfall. Because these data relate to low permeable soils, rapid drops in matrix pressure head appear to be connected both to matrix fluxes in the nearly saturated material and to fissure fluxes. A similar behaviour has been observed for slow-moving landslides including fissured clays (Baum and Reid, 1995).

Cross-association analysis between onset of effective precipitation and onset of soil moisture changes was performed to determine the time delay in the infiltration process (Fig. 4d). The precipitation and soil moisture data are on a hourly basis, therefore the matching was performed on the same time scale. It is recognised that this time resolution is high for infiltration in semi-permeable soil. All soil moisture time series give similar results for the cross-association analyses. Results show a maximum time lag of $4 \mathrm{~h}$ for the upper part of the unsaturated zone $(-0.56 \mathrm{~m})$, and a maximum of 9 to $10 \mathrm{~h}$ for the lower part (between $-0.88 \mathrm{~m}$ and $-1.08 \mathrm{~m}$ ). The percentage of matches decreases between time lags of 4 to $9 \mathrm{~h}$ for the upper part of the unsaturated zone, and between time lags of 9 to $15 \mathrm{~h}$ for the lower part. Results indicate that the unsaturated zone generally reacts within $4 \mathrm{~h}$ on a rain event.

\section{Concept for the hydrology of the earthflow and model implementation}

\subsection{The hydrological concept}

We propose the following conceptual hydrological model:

- above a certain groundwater threshold level (0.6-0.8 m in the HG1 unit, $0.8-1 \mathrm{~m}$ in the HG2 unit), groundwater fluctuations are invariably rapid (less than a few hours), of moderate magnitude $(0.1-0.4 \mathrm{~m})$ and relatively short duration (within days) following liquid rainfall. Peaks following snowmelt have a longer duration;

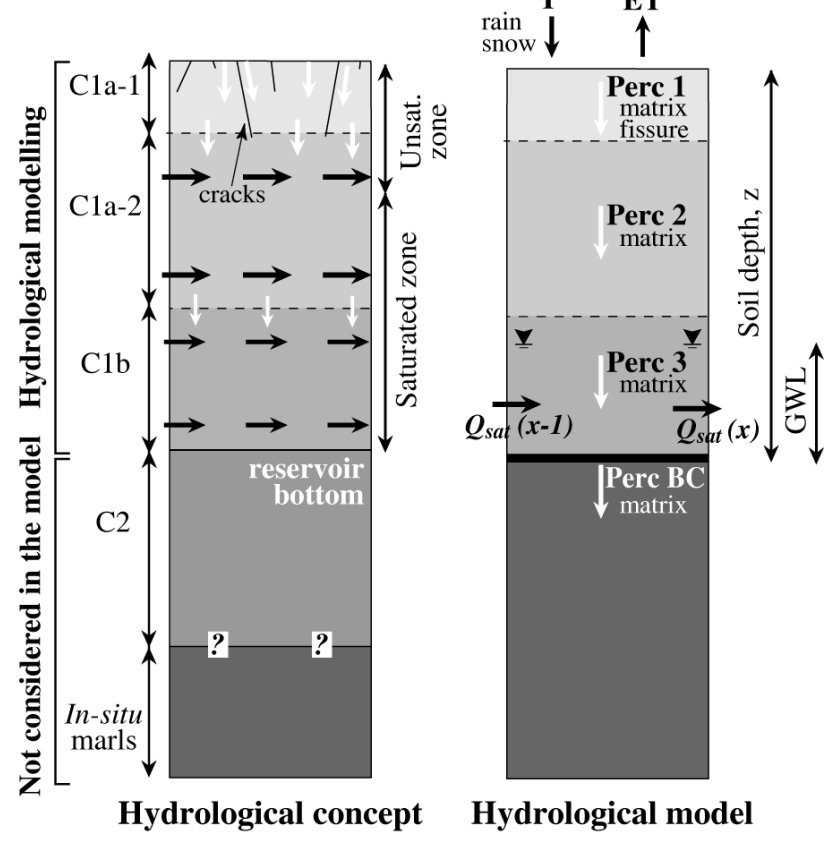

Fig. 5. Hydrological concept of the earthflow and schematisation of the concept implemented in the hydrological model.

- the decline of the groundwater levels below this threshold strongly depends on the season, with faster drainage in summer;

- the hydrological regime is influenced by two important recharge events, one at the end of spring and one at the beginning of autumn;

- no deep alimentation occurs within the landslide body.

The rapid piezometric responses are attributed to matrix fluxes in nearly saturated materials, combined to fissure fluxes through a superficial $(0.3-1 \mathrm{~m})$ system of interconnected cracks. The depth of this crack system is similar to the boundary between the unsaturated and saturated zones. Contribution of fissure flow to the recharge of the groundwater table is not the same for all the measurements stations due to differences in crack density and soil surface characteristics, so it can be considered as one of the main reasons for the spatially varying rates of groundwater rise.

The relation between precipitation and piezometric variations can not be ascribed only to vertical infiltration; lateral infiltration can also play an important role. These considerations are schematised into a hydrological concept with three layers (Fig. 5). A layer with a continuous permeable crack system $\left(\mathrm{C} \mathrm{a}_{1}\right)$ overlies two layers marked by different hydraulic conductivity values $\left(\mathrm{Cla}_{2}, \mathrm{C} 1 \mathrm{~b}\right)$ due to compaction. The groundwater table is mainly located in the $\mathrm{C} 1 \mathrm{~b}$ and $\mathrm{C}_{1} \mathrm{a}_{2}$ layers. The lower unit $(\mathrm{C} 2)$ and in-situ marls are relatively impervious and thus not considered in the hydrological model. A similar concept has been proposed in the Alverà landslide (Angeli et al., 1998; Bonomi and Cavallin, 1999). 


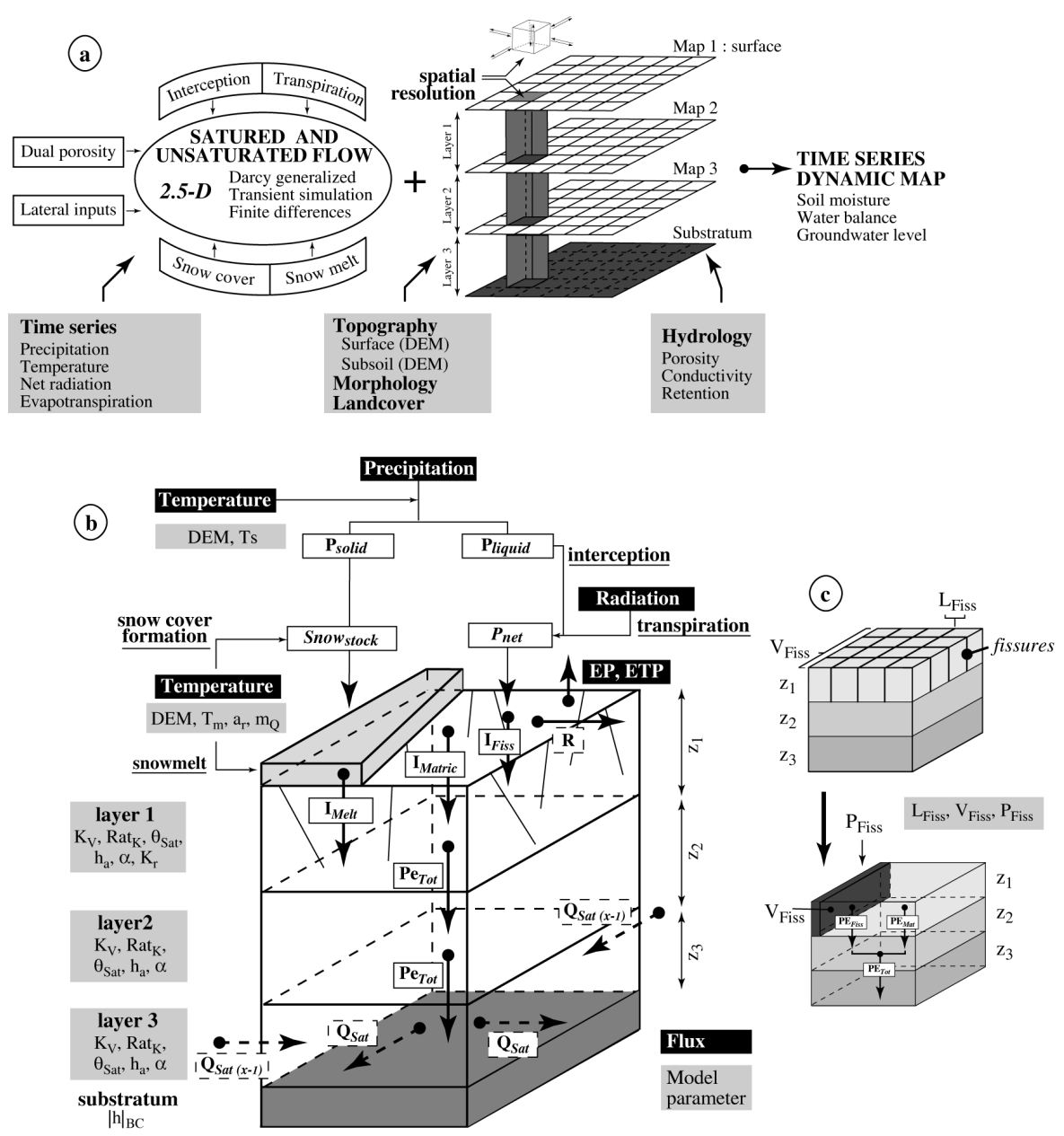

Fig. 6. Architecture of the STARWARS model. ((a) Modular architecture of the model (core model, sub-model) and schematic representation of the model implementation in the pcraster gis package. (b) Representation of the storages and fluxes represented by the model, and relation between the calculation cells. (c) Schematic representation of the three-parameter conceptual fissure flow model. Definitions of the parameters are listed in Table 1.

We incorporated this hydrological concept into a numerical model (Fig. 6a) by adaptating the spatially distributed physically based model STARWARS (Storage and Redistribution of Water on Agricultural and Revegetated Slopes) developed by Van Beek (2002) for the simulation of catchment hydrology.

\subsection{The hydrological model STARWARS}

The hydrological model STARWARS uses the embedded meta-language of the pcraster gis package (Wesseling et al., 1996). The full model is built around a core model resolving the dynamic equation for saturated and unsaturated flows and additional sub-models describing specific hydrological processes (Fig. 6a). The model uses measured distributed values for the parameter values. Each layer is represented by a 2-D map (Fig. 6a). Implementation in a GIS-environment has several advantages. First of all, if based on a high resolution DEM, the effect of topography can readily be incorporated; secondly, GIS offers the use of directly available routing functions to define flow paths in each layer. Thirdly, it is possible to include the spatial variation (horizontal and vertical) of the hydrological parameters. This approach provides a unified theoretical description of most of the water fluxes observed within a landslide.

The hydrological model consists of three permeable reservoirs (three layers) and an underlying impervious bedrock. The hydrological model describes the saturated and the unsaturated transient flow in the vertical and horizontal directions assuming freely drainable water (Figs. 6a, 6b). Storage and fluxes are considered: antecedent soil moisture in the different reservoirs, infiltration $I$, evaporation $E p$, surficial runoff $R$, percolation in the unsaturated zone $P e$ and saturated lateral flow $Q_{\text {sat }}$ define the hydrological balance of the system. A complete mathematical description of the model can be found in van Beek (2002).

Within each timestep, water is added to the saturated storage of each reservoir by the percolation from the unsaturated zone and by bypass flow in the fissures $I_{\text {Fiss }}$ and di- 
rect infiltration of snowmelt water $I_{\text {Melt }}$ in the upper reservoir (Fig. 6b). As first approximation, percolation is limited to gravitational vertical flow and defined as a function of the elevation potential only neglecting the matrix potential for the flow in the unsaturated zone. The saturated storage is diminished by the loss over the impervious bedrock and by evaporation, which is only substantial when the groundwater is close to the surface. In the saturated zone, the piezometric head defines the lateral flow. All storage and fluxes are expressed by the relative degree of saturation $\theta_{E}$ of each layer and given in units of waterslice $(m)$. For each model layer $z$, the vertical unsaturated matric flow (the percolation) is controlled by the unsaturated hydraulic conductivity $K\left(\theta_{E}\right)$. The mathematical formulation of Farrel and Larson (1972) of the Soil Water Retention Curves, combined to the capillary analogy of Millington and Quirk (1961), and the saturated vertical conductivities $K_{V}$ are used for the calculation of the unsaturated conductivity. Percolation is thus proportional to the travel time of soil moisture through the unsaturated zone, and is deducted directly from the drainable storage in the unsaturated zone. It is then used to recalculate the resulting degree of saturation for the next timestep. As a dual porosity network exists in the upper layer, bypass flow through the fissures is also considered.

The lateral outflow $Q_{\text {sat }}$ over the saturated zone is controlled by the piezometric gradient $i$, defined by the absolute elevation of the phreatic surface. This hypothesis assumes horizontal flow in the satutrated zone. A Local Drainage Direction map (LDD) of the groundwater height is derived to identify the drainage direction. The piezometric gradient $i$ is given by the difference in elevation over the slope parallel distance. Along the LDD, the lateral outflow travels with the apparent velocity of a saturated horizontal conductivity $K_{H}$, which is a fraction of the vertical saturated conductivity $K_{V}$. Then, for each cell, the storage in the saturated zone is balanced for the outgoing and incoming fluxes.

The generation of the groundwater is simulated by imposing boundary conditions (Fig. 6b). The lower boundary conditions are state-controlled and are specified as fixed values for the matric suction. The upper boundary conditions are flux-controlled and account for the meteorological inputs at the surface (rainfall, temperature, evaporation, net radiation). At the surface, a simple infiltration module is used assuming that the maximum infiltration capacity is defined as a ratio of the rainfall to the top layer saturated conductivity. The infiltration is only limited if the net rainfall exceeds the later.

A snowpack and snowmelt sub-model is incorporated as a pre-processor in the hydrological model (Fig. 6b). A simple conceptual approach describing the energy balance of the topsoil from the times series of net radiation and temperature was used. The model is based on three components: (1) an input transformation, correcting climatic inputs (precipitation, temperature and radiation) with respect to altitude, (2) a surface melt component using a simple excess temperature mechanism as a substitute for a full energy budget controlled melt formulation, (3) a snowpack storage term $m_{Q}$ controlling how surface melt is retained within the pack, and
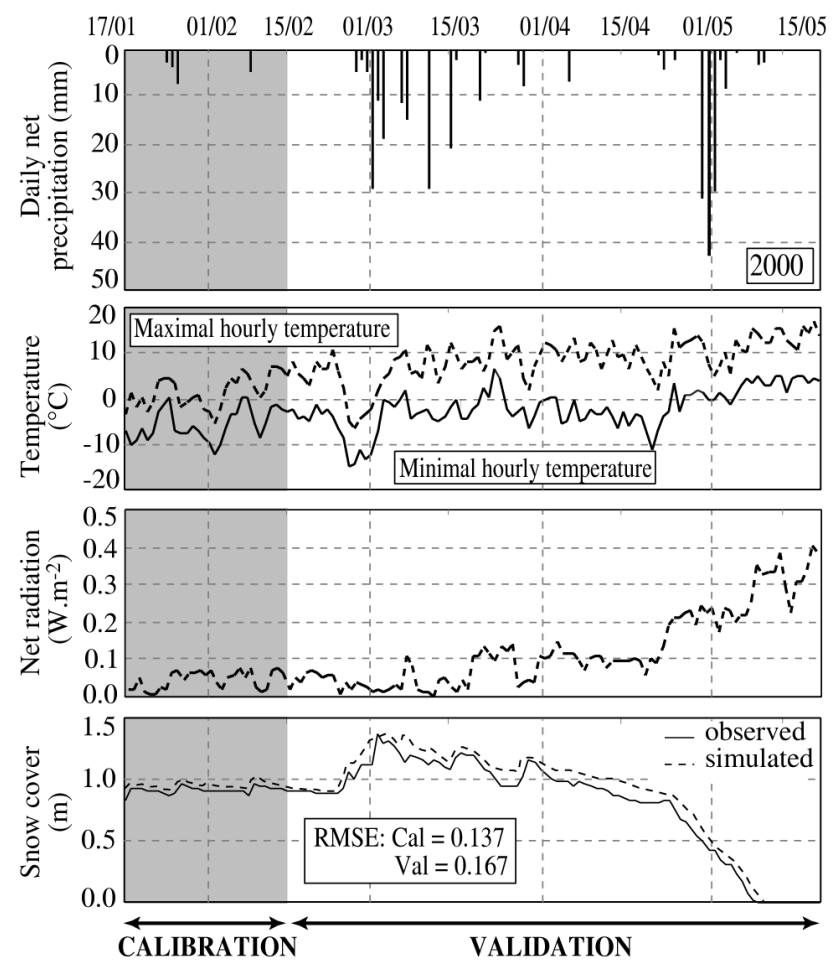

Fig. 7. Calibration and validation of the snowpack/melt model over the winter of year 2000 .

consequently defining the release of water from the pack. The snowpack/melt model employs representations particularly suited to South Alps conditions. A temperature threshold $(T s)$ is used to discriminate rainfall ( $\left.P_{\text {liquid }}\right)$ from snowfall $\left(P_{\text {solid }}\right)$. A critical temperature $(\mathrm{Tm})$ above which melt $\left(I_{M}\right)$ occurs and a melt factor $\left(a_{r}\right)$ are used to govern the melt equation.

A simple conceptual fissure flow sub-model was developed to represent shallow bypass flow in an implicit form. In each layer, the volume of each cell is disaggregated into equivolumes of soil matrix separated by equi-volumes of fissures (Fig. 6c). Each equi-volume can be calculated using the combination of two variables: the fraction occupied by the fissures $V_{\text {Fiss }}$ and the mean opening of the fissures $L_{\text {Fiss. }}$. Using these parameters has practical utility because they can be easily estimated in the field and represented on maps. At each time step, the unsaturated flow in excess is directed towards the fissure and that volume of water is transferred directly towards layer $\mathrm{Cl}_{2}$ within one timestep by bypass flow. The flow in the reverse direction, from the saturated fissures to the matrix, is not considered. Moreover a sink term $P_{\text {Fiss }}$ is used to transfer a fraction of the precipitation in excess (i.e. in excess to the infiltration capacity of the topsoil) directly to depth within one time step. The fissure flow sub-model has been developed to take into account fissures in the three layers; nevertheless, in our simulations, only the upper layer $\mathrm{C} 1 \mathrm{a}_{1}$ is fissured. 
Table 1. Overview of the field-measured parameters and of the best-fit parameters for the optimisation of the hydrological core model.

\begin{tabular}{|c|c|c|c|c|c|}
\hline \multirow[t]{2}{*}{ Parameters } & \multirow[t]{2}{*}{ Description } & \multicolumn{3}{|c|}{ Field measurements } & \multirow[t]{2}{*}{ Best-fit model values } \\
\hline & & Mean & Range & $n$ & \\
\hline$K v_{1}\left(\mathrm{~cm} \cdot \mathrm{d}^{-1}\right)^{*}$ & Saturated vertical conductivity $-\mathrm{C} \mathrm{a}_{1}$ & 0.78 & $0.53-0.91$ & 131 & 0.40 \\
\hline$K v_{2}\left(\mathrm{~cm} \cdot \mathrm{d}^{-1}\right)^{*}$ & Saturated vertical conductivity $-\mathrm{C} \mathrm{a}_{2}$ & 0.53 & $0.42-0.72$ & 86 & 0.30 \\
\hline$K v_{3}\left(\mathrm{~cm} \cdot \mathrm{d}^{-1}\right)^{*}$ & Saturated vertical conductivity $-\mathrm{C} 1 \mathrm{~b}$ & 0.47 & $0.35-0.52$ & 47 & 0.30 \\
\hline $\operatorname{Rat}_{K}(-)$ & Ratio Horizontal/Vertical conductivity & 0.46 & $0.39-0.56$ & 67 & 0.01 \\
\hline$q_{\mathrm{Sat}_{1}}(-)^{*}$ & Porosity value $-\mathrm{C} \mathrm{a}_{1}$ & 0.43 & $0.36-0.49$ & 142 & 0.38 \\
\hline$q_{\mathrm{Sat}_{2}}(-)^{*}$ & Porosity value $-\mathrm{C} 1 \mathrm{a}_{2}$ & 0.37 & $0.30-0.46$ & 93 & 0.24 \\
\hline$q_{\mathrm{Sat}_{3}}(-)^{*}$ & Porosity value $-\mathrm{C} 1 \mathrm{~b}$ & 0.31 & $0.23-0.39$ & 61 & 0.21 \\
\hline$H a_{1}(m)^{*}$ & Air entry value - C1a 1 (SWRC) & 0.024 & $0.008-0.042$ & 142 & 0.021 \\
\hline$\alpha_{1}(-)^{*}$ & Shape factor of the SWRC $-\mathrm{C} \mathrm{a}_{1}$ & 13.6 & $12.9-14.7$ & 142 & 10.1 \\
\hline$h a_{2}(m)^{*}$ & Air entry value $-\mathrm{C}_{1} \mathrm{a}_{2}(\mathrm{SWRC})$ & 0.042 & $0.035-0.049$ & 93 & 0.031 \\
\hline$\alpha_{2}(-)^{*}$ & Shape factor of the SWRC $-\mathrm{C} 1 \mathrm{a}_{2}$ & 12.3 & $11.5-13.1$ & 93 & 7.1 \\
\hline$h a_{3}(m)^{*}$ & Air entry value - C1b (SWRC) & 0.021 & $0.016-0.021$ & 61 & 0.017 \\
\hline$\alpha_{3}(-)^{*}$ & Shape factor of the SWRC $-\mathrm{C} 1 \mathrm{~b}$ & 13.2 & $12.3-13.7$ & 61 & 10.0 \\
\hline$K_{R}(-)^{* *}$ & Runoff coefficient & 0.2 & $0.1-0.4$ & 35 & 0.35 \\
\hline$|h|_{B C}(m)$ & Matric suction at the bedrock interface & - & - & - & 2.98 \\
\hline
\end{tabular}

\section{Model calibration and optimisation of model perfor- mance}

\subsection{Model calibration}

We identified a compromise between the complex topography, the spatial distribution of soil properties, the temporal resolution of the meteorological and hydrological records to set the spatial resolution at a pixel of $2 \times 2 \mathrm{~m}$ and the timestep resolution at $6 \mathrm{~h}$. The model formulation was defined a priori and calibration only consists of optimisation of the model performance by adapting the hydrological parameters on the basis of field evidence. In a first stage of model development, the piezometers EV2 and BV16 were chosen as calibration sites (Fig. 2a). The model was calibrated over the period April-June 2000. To produce an initial distributed water level, soil moisture and snow thickness conditions, the model was run over a 25-years period using the meteorological data of Barcelonnette (1975-2000) and the average hydrological parameters measured in the field. To test the model capabilities, we performed some simple initial calculations assuming a vertical and spatial differentiation of the parameters. These results are presented and discussed in the following section.

As a first stage, the snowpack/melt sub-model parameters ( $T s, T m, a_{r}, m_{Q}$ ) were calibrated separately using the continuous snow thickness data measured in the winter of year 2000 (Fig. 7). The calibration was performed by an automated iterative procedure using the Marquardt-Levenberg algorithm (Marquardt, 1963) implemented in the pest code (Model-Independent Parameter Estimation, Parameter Estimation Inc., 1999). A plausible set of initial parameters, as well as a maximum and a minimum value, were introduced in the optimisation process. The calibration was per- formed on a short period ( 1 month) to test the performance of the model. The best calibration fit was found for $a_{r}=0.28$, $m_{Q}=0.042$, a $T_{s}$ temperature of $2^{\circ} \mathrm{C}$ and a $T m$ temperature of $-0.5^{\circ} \mathrm{C}$. These values are within the range given by Martinec et al. (1994) for the South Alps. Figure 7a represents the observed and simulated time series for the calibration and validation periods. The Root Mean Squared Error (RMSE) is used to estimate the quality of the simulation.

As a second stage, the fissure flow sub-model, combined with the core hydrological model, was calibrated using two rainfall events (characteristic of a wet period and a dry period) with observed soil moisture variations at $-0.56 \mathrm{~m}$ and $-1.08 \mathrm{~m}$ at site EV2. The average values for six parameters of the core model $\left(\theta_{\text {Sat }}, \alpha\right.$, Rat $\left._{K},|h|_{B C}, K_{R}\right)$ were used (Table 1 ); the vertical saturated conductivity $K_{V}$ was optimised. Figure 8 shows an example of the results for rainfall in a wet period (initial soil moisture $>35 \%$ ) and rainfall in a dry period (initial soil moisture between 25 and 30\%). The simulated time series "with fissures" and "without fissures" (ie. only with a matric percolation) are shown, as well as the calculated RMSE's

As can be observed, the RMSE's are better for the simulations performed with fissures (Fig. 8). Introducing a rapid flux towards depth appears to be a simple solution for decreasing the soil response time, while keeping a coherent vertical saturated conductivity for the matrix. Simulations shows that daily water flows drained by the cracks account for approximately $15 \%$ of total flow drained at the contact $\mathrm{C} 1 \mathrm{a}_{1} / \mathrm{C} 1 \mathrm{a}_{2}$. This fraction is sufficient to obtain fast reactions within the upper part of the landslide body. The best-fit average parameters of the fissure flow sub-model are $V_{\text {Fiss }}=0.103$, $L_{\text {Fiss }}=0.042 \mathrm{~mm}$, and $P_{\text {Fiss }}=0.036$. these avalues are in accordance to field observations (Malet et al., 2003). 
Table 2. Validation results of the STARWARS model: GWL stands for fitting on the groundwater levels time series at two piezometric stations, SM stands for the fitting on the soil moisture time series at four depths, RMSE stands for root mean squared error, Ratio stands for the ratio of RMSE of validation period over RMSE of the calibration period.

\begin{tabular}{|c|c|c|c|c|c|c|c|c|c|}
\hline & $\begin{array}{c}\mathrm{Cal}^{*} \\
\operatorname{RMSE}(m)\end{array}$ & $\begin{array}{c}\text { Val } \\
\text { RMSE }(m)\end{array}$ & $\begin{array}{c}\text { Ratio } \\
\text { Val/Cal }\end{array}$ & $\begin{array}{c}\mathrm{Cal}^{* *} \\
\operatorname{RMSE}(m)\end{array}$ & $\begin{array}{c}\text { Ratio } \\
\text { Val/Cal }\end{array}$ & $\begin{array}{c}\mathrm{Cal}^{* * *} \\
\operatorname{RMSE}(m)\end{array}$ & $\begin{array}{c}\text { Ratio } \\
\text { Val/Cal }\end{array}$ & $\begin{array}{c}\mathrm{Cal}^{* * * *} \\
\operatorname{RMSE}(m)\end{array}$ & $\begin{array}{c}\text { Ratio } \\
\text { Val/Cal }\end{array}$ \\
\hline GWL (2) & 0.301 & 0.432 & 1.433 & 0.335 & 1.302 & 0.285 & 1.274 & 0.510 & 1.270 \\
\hline SM (4) & 0.277 & 0.391 & 1.444 & 0.287 & 1.384 & 0.224 & 1.129 & 0.428 & 1.259 \\
\hline
\end{tabular}

\footnotetext{
* Represents model calibration on a calendar year (January-December);

** Represents model calibration on a hydrological year (September-August);

*** Represents model calibration on three groundwater table recharge periods;

**** Represents model calibration on three groundwater table drainage periods.
}

Finally, in a third stage, the core model was calibrated. Table 1 gives an overview of the mean values and estimated ranges of model parameters obtained from laboratory and field investigations. As described above, model optimisation is performed with the pest code by defining a plausible range of parameters values. Therefore upper and lower boundaries conditions $( \pm 50 \%$ of the minimal and maximal measured values) were fixed for each parameter. The bestfit parameters obtained by inverse modelling for the snowpack/melt sub-model and the fissure flow sub-model were used. The others parameters were adjusted to come to the smallest RMSE for the observed versus simulated time series. The optimized values are very close to the range of values measured in the field (Table 1).

Figure 9 shows the simulation results for piezometers EV2 and BV16. The response pattern is reproduced well; although some recorded peaks, especially for BV16, are underestimated or missed. This underestimation is less important because these short-lived high groundwater levels do not influence the kinematics of the earthflow (Malet et al., 2002).

The drainage conditions and the range of groundwater levels fluctuations are well simulated. This indicates that the estimation of the evaporation parameters by the Penman formula is adequate. However, the quickness of important recharge events (often less than one day) is not simulated by the model; instead, the duration of the simulated recharge is spread out over several days. We assume that a more detailed spatial representation of the parameters with higher conductivity values, porosity values and density of fissures in the upper part of the earthflow, would help reduce this mismatch. In addition, the Snow Water Equivalent simulated during the melting of the snow cover is underestimated, because the density of the snow is not used in the model.

Two important aspects of a model are its performance after the calibration period and the choice of the fitting time series. In our case, the modelled time series can be optimised on the soil moisture variation in the topsoil (at 4 depths) or on the groundwater levels. Table 2 shows the results of RMSE calculated for the calibration and validation periods, as well as the ratio for the two periods. Table 2 shows that the model performance is slightly better with the soil moisture data set
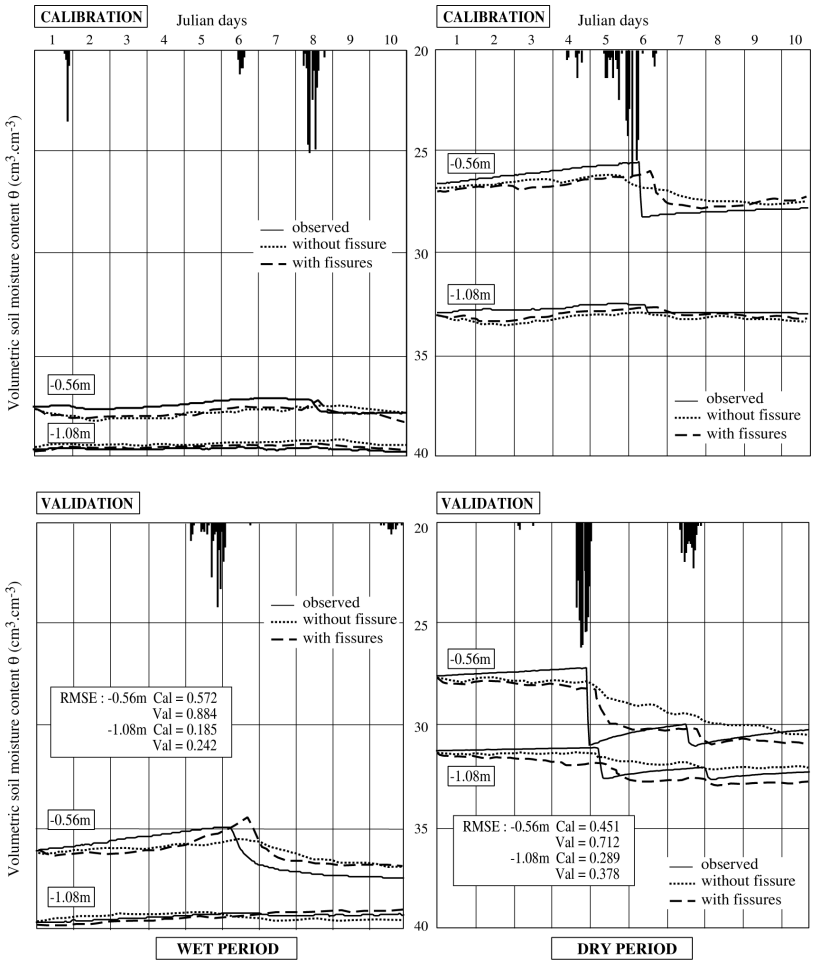

Fig. 8. Calibration and validation of the fissure flow model for a period of initial wet conditions in the upper layer and a period of initial dry conditions in the upper layer. RMSE's are indicated for the simulations "with fissures".

than with the groundwater level data set. This result is not surprising as the generation of the groundwater table in the soil by downward percolation is controlled by the soil moisture balance in the topsoil (Van Beek, 2002). Calibration with the groundwater levels necessitates some additional parameters to optimise. Moreover, the optimisation performed solely on the drainage periods results in higher RMSE's. This result also implies that the soil moisture balance and the evaporation process are well represented by the model. However, the recharge periods are poorly represented. This can be explained by an underestimation of the fissure flow. Finally, results show that the model performance is gener- 

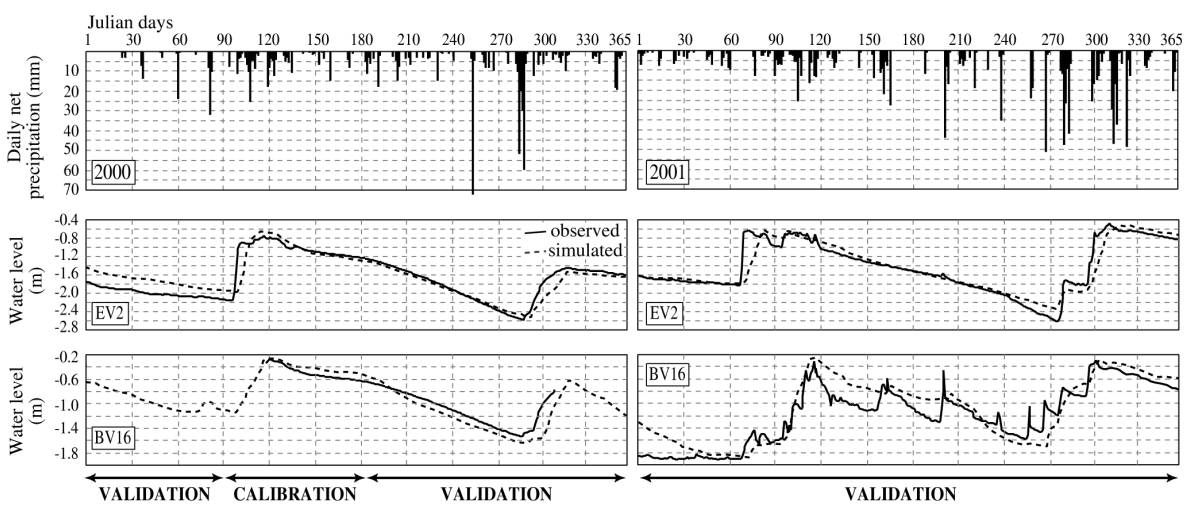

Fig. 9. Observed and simulated groundwater levels over years 2000 and 2001, and corresponding calibration and validation periods. The time series are optimised against the observed soil moisture data.
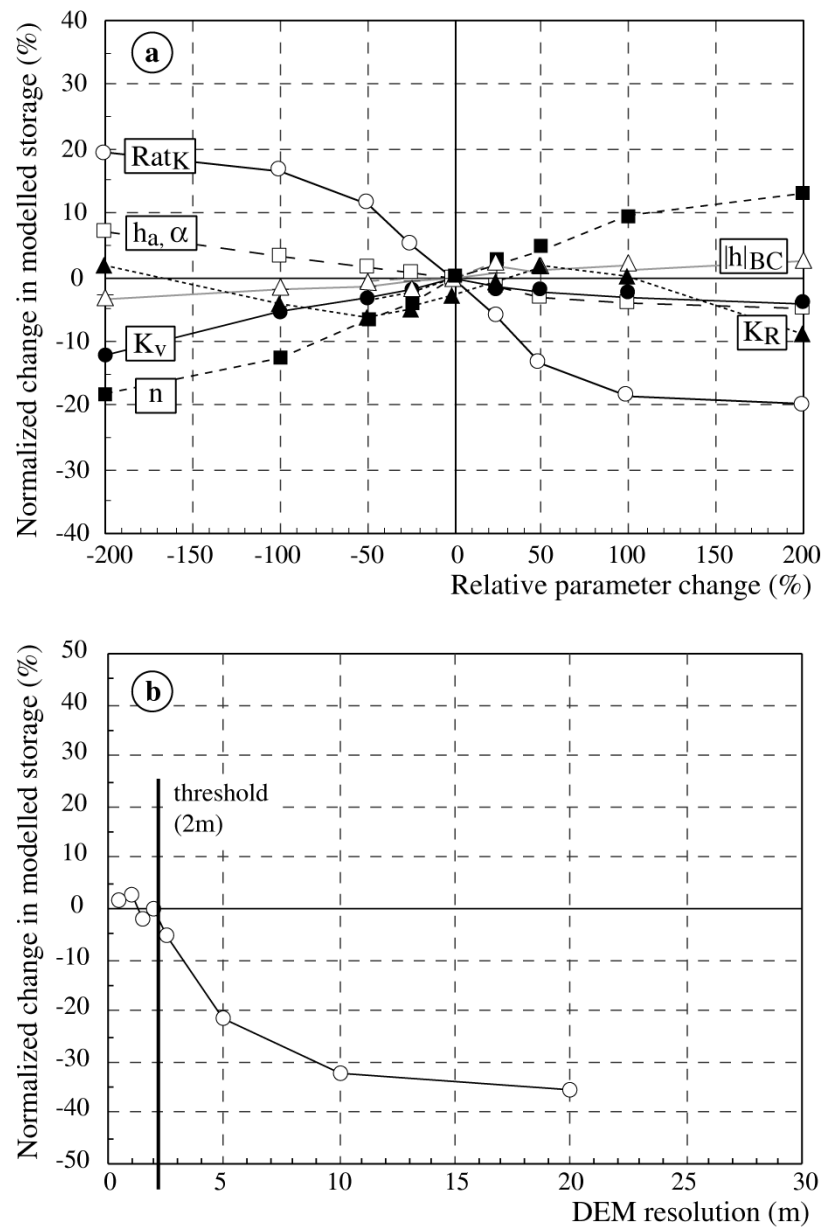

Fig. 10. Sensitivity of the simulated hydrology, expressed as the change in total storage, to changes in seven model parameters (a) and DEM resolution (b).

ally poorer in the validation period. Longer training data sets might improve overall model performance.

Table 1 shows the best-fit parameters resulting from the optimisation process. Best-fit parameters are in the range of parameters estimated in the field. The porosities values, $\theta_{\text {Sat }}$, the ratio between horizontal and vertical conductivity, Rat $_{K}$, the SWRC parameters, and the matrix suction at the bedrock interface, $|h|_{B C}$, which controls the loss of water in the lower unit are the main controlling parameters.

\subsection{Model sensitivity}

The sensitivity of the model to changes in parameterisation and in model geometry was analysed by comparing the simulated hydrology of the earthflow for the year 1999. The total drainable storage was used as a general measure of the simulated hydrology. Starting with the same initial conditions (an average winter profile of moisture content), the soil moisture in the three layers and the groundwater levels were modelled with the input climate data of 1999 . The tested parameters $\left(K v\right.$, Rat $\left._{K}, \theta_{\text {Sat }}, h a_{1}, \alpha_{1}, K_{R},|h|_{B C}\right)$ were varied in consecutive model runs and model outcomes were compared to those with the reference parameterisation, following the procedure proposed by Van Beek (2002). Only one parameter was perturbed in each run. The remaining parameters were kept at constant values. The model is simplified by assuming only one hydrogeomorphological unit. The parameter changes were calculated by subtracting or adding $10 \%, 25 \%$, $50 \%, 100 \%$ and $200 \%$ of the standard deviation of the mean parameter value (Fig. 10a). If the variability was unknown, an estimate was used.

The hydrological model is most sensitive to the ratio between the vertical and horizontal saturated conductivity (Fig. 10a). A change by $\pm 25 \%$ of the ratio results in a deviation of more than $15 \%$ in the modelled storage. This ratio is therefore a suitable parameter for model calibration. Porosity and density of cracks are the parameters with the second and third largest influences. This is not surprising because these two parameters control the soil moisture percolation in depth, and thus the overall infiltration process. The others parameters have less influence with deviations in drainable storage of less than 5\%. Among these other parameters, the characteristics of the soil water retention curves have the highest influence. Results of this sensitivity analysis con- 


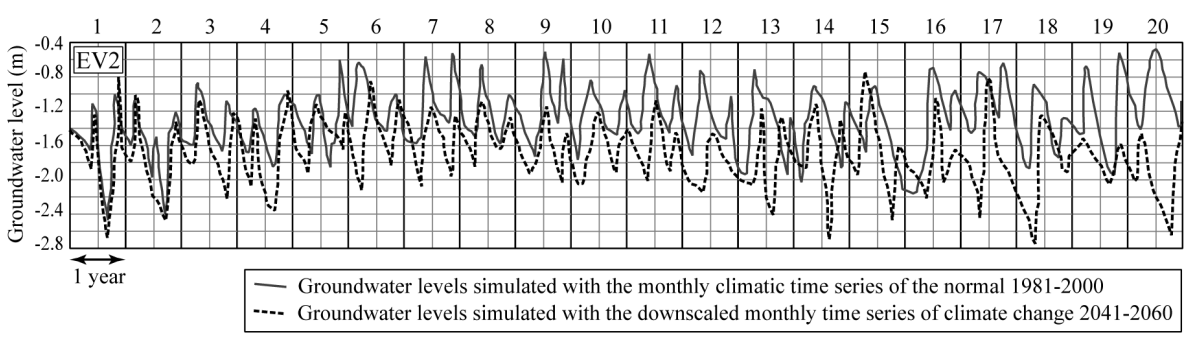

Fig. 11. Simulation of the earthflow's hypothetical hydrological regime over the periods from 1981 to 2000 and 2041 to 2060 assuming the climatic change scenario proposed by Buma and Dehn (1998) for the Barcelonnette Basin.

firm those obtained by Van Beek (2002). In Fig. 10b, the normalized changes in modelled storage are given for different simulations with different cell size, by keeping all the other input parameter values constant. DEM resolution has a high influence. Coarse resolution (larger than $5 \mathrm{~m}$ ) results in an underestimation of more than $20 \%$ in the modelled storage. A threshold is clearly identified around $2 \mathrm{~m}$. Below this threshold, integration of finer resolution does not degrade or improve the model results.

\section{Model forecasts and practical use}

After the model appears to give an accurate representation of the physical processes being in consideration, it can then be applied to hypothetical cases. Two examples of potential practical applications are presented below.

\subsection{Long-term behaviour of the flow: impact of environ-} mental changes

The dynamic nature of this type of model allows us to test the influence of changes in climate or land use on the landslide hydrological behaviour. These elements can aid an expert responsible for defining hazard levels. Numerical simulations were conducted, first using the monthly time series of rainfall and temperatures at the Barcelonnette climatic station (19812000) and second, using the monthly time series provided by a downscale Global Change Model (2041-2060). The data used are from Buma and Dehn (1998). Figure 11 illustrates the reconstitution of the earthflow's hydrological behaviour driven by these climate variations. The results must be interpreted cautiously, first because this approach presupposes that the geometry of the moving mass does not vary over the simulated period, and second because of the extreme variability of the outputs from Global Change Models. It appears that over the period 1981-2000, the general simulated trend (two recharge episodes by year, higher groundwater levels in winters with a large amount of snow) is similar to the one observed over the period 1997-2000. It is remarkable to observe that the period from 1985 to 1991 presents a succession of high groundwater levels, which also corresponds to period of the earthflow's fastest motion (Malet and Maquaire, 2003). In the period from 2041 to 2060 there is a decrease in the average groundwater level of the earthflow. Over the long- term, the series also demonstrate a dramatic change in the earthflow's hydrologic behaviour with many years showing only a single recharge episode. The return frequency of high groundwater levels (higher than the threshold for movement acceleration) would thus tend to diminish.

\subsection{Behaviour of the earthflow with grass or tree planting}

A second practical example is the simulation of the earthflow's hypothetical hydrological behaviour with additional grass or tree planting. The effect of ecological engineering such as artificial planting can be assessed using the model with a view to reducing landslide hazard. To accomplish this, a sub-model representing the manner in which vegetation intercepts rainfall (i.e. a fraction of the gross rainfall function of the foliar index) and an evapotranspiration sub-model (i.e. a fraction of the potential evapotranspiration reduced by a scale factor $k_{c}$, representing the various vegetation cover) were integrated into the model (Van Beek, 2002).

Three scenarios of ecological engineering were examined: grass seeding, conifers planting (20-year-old black pines), and a mixed scenario (Fig. 12). The simulations were carried out using input data from 1999. Simulations show that the influence of grass seeding is almost negligible on the hydrological behaviour, however, conifer planting considerably lowers the piezometric level to a maximum height of around $-0.80 \mathrm{~m}$ and modifies the rate of drainage. The spatial localisation of the trees can also be optimised. It appears that tree planting only upstream of the earthflow causes a decrease in the groundwater level of around $0.50 \mathrm{~m}$ (Fig. 12, Scenario B).

\section{Conclusions}

This paper describes an initial attempt to model the hydrology of a clay-shale slow-moving earthflow, whose behaviour is governed by seasonal pore pressure fluctuations. To understand the influence of rainfall recharge on spatially variable groundwater flows, detailed rainfall and ground-water data were collected. The observed time-dependent hydrological behaviour is well reproduced by a distributed physically based model in three layers. The model has appears to capture all the necessary physical phenomena with sufficient ac- 

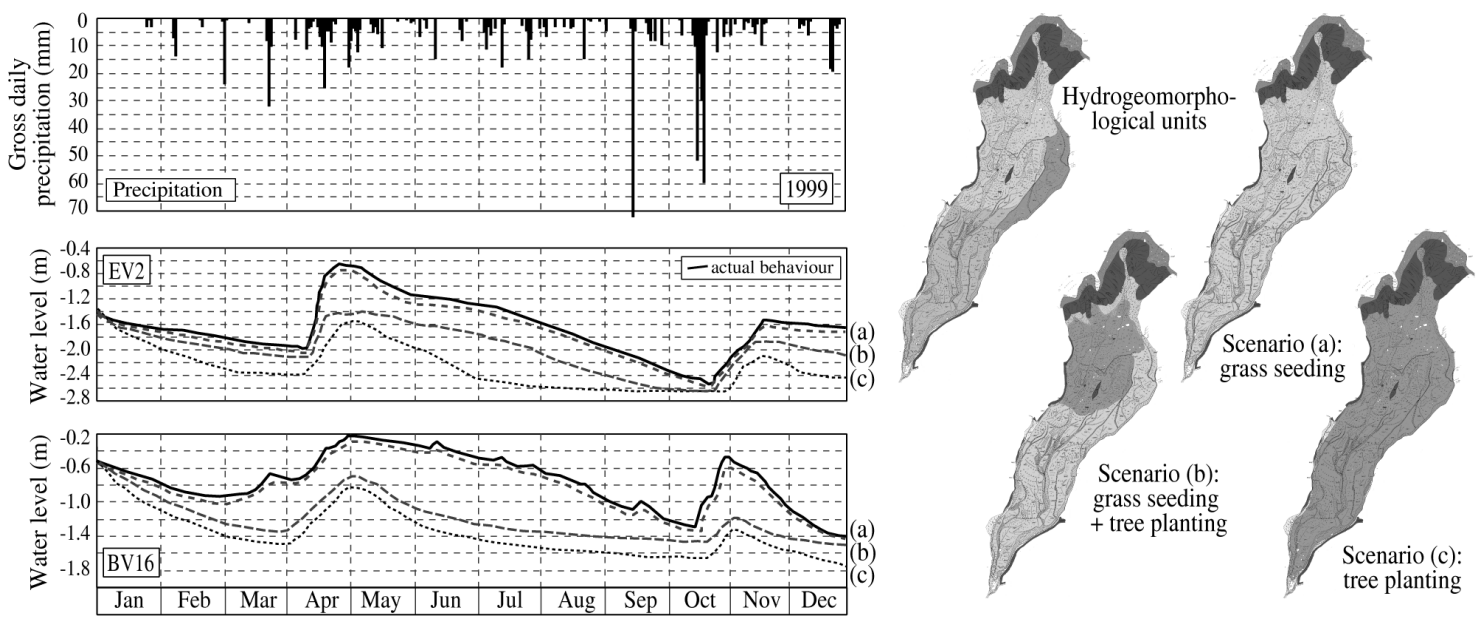

Fig. 12. SInfluence of ecological engineering (three scenarios) on the hypothetical hydrological behaviour of the earthflow.

curacy to simulate and provide quantitative description of the hydrological behaviour.

Model outputs are quite sensitive to changes in the effective porosity values and conductivity values. In the current model, recharge within the fissures is very low; some specific research should be performed on this topic. Also, considerable simplification was introduced by assuming constant porosity values instead of possible transient values caused by the swell-shrink behaviour of the earthflow material or compaction due to the movement.

It should be recalled that this type of model is only one of the tools available to the expert to aid in forecasting future behaviour (depending on his intuition, his experience, and on field observations). Although the model does not claim to simulate all behaviour, nevertheless it does provide a means establishing the influence of certain parameters and thereby reducing the subjectivity of assessments. Further research on landslide hydrology should nevertheless be undertaken in the future, on the basis of the different landslide databases now available.

Acknowledgements. This research was supported by the European Community in the framework of the FP5 ALARM Project (Assessment of Landslide Risk and Mitigation in Mountain Areas), by Centre National de la Recherche Scientifique (CNRS) within the framework of INSU-PNRN (Project ECLAT: Ecoulement, initiation et Contribution des Laves Torrentielles dans les bassins marneux) and the French Ministry of Research within the ACI-CatNat Project MOTE (MOdélisation, Transformation, Ecoulement des coulées boueuses dans les marnes). The authors are grateful to S. Silvano and an anonymous reviewer for their precious advices. Contribution INSU No. 412. Contribution EOST No. 2004.089-UMR7516.

Edited by: G. B. Crosta

Reviewed by: S. Silvano and another referee

\section{References}

Ambroise, B.: La dynamique du cycle de l'eau dans un bassinversant. Processus, facteurs, modèles, Editions ${ }^{*} \mathrm{H}^{*} \mathrm{G}^{*} \mathrm{~A}, \mathrm{Bu}-$ carest, 1999.

Anderson, M. G. and Kemp, M. J.: Application of soil water finite difference model to slope stability problems, in Proc. of the $5^{\text {th }}$ International Symposium on Landslides, Lausanne, (Ed) Bonnard, 525-531, 1988.

Anderson, M. P. and Woessner, W. W.: Applied Groundwater Modelling. Simulation of Flow and Advective Transport, Academic Press, London, 1991.

Angeli, M. G., Buma., J., Gasparetto, P., and Pasuto, A.: A combined hillslope hydrology/stability model for low gradient clay slopes in the Italian Dolomites, Engineering Geology, 49, 1-13, 1998.

Antoine, P., Giraud, A., Meunier, M., and Van Asch, Th. W. J.: Geological and geotechnical properties of the 'Terres Noires' in the southeastern France: weathering, erosion, solid transport and instability, Engineering Geology, 40, 223-234, 1995.

Baum, R. L. and Reid, M. E.: Geology, hydrology, and mechanics of a slow-moving, clay-rich landslide, Honolulu, Hawaii; Geological Society of America, Reviews in Engineering Geology, Vol. X, 79-105, 1995.

Bonomi, T. and Cavallin, A: Three-dimensional hydrogeological modelling application to the Alverà mudslide (Cortina d'Ampezzo, Italy), Geomorphology, 30, 1-2, 189-199, 1999.

Brooks, S. M., Crozier, M. J., Preston, N. J., and Anderson, M. G.: Regolith stripping and the control of shallow translational hillslope failure: application of a two-dimensional coupled soil hydrology-slope stability model, Hawke's Bay, New Zealand, Geomorphology, 45, 3-4, 165-179, 2002.

Brunsden, D.: Some geomorphological considerations for the future development of landslide models, Geomorphology, 30, 1-2, 13-24, 1999.

Buma, J. and Dehn, M.: A method for predicting the impact of climate change on slope stability, Environmental Geology, 35, 2-3, 190-196, 1998.

Cappa, F., Guglielmi, Y., Merrien-Soukatchoff, V., Mudry, J., Bertrand, C., and Charmoille, A.: Hydromechanical modeling of a large moving rock slope inferred from slope levelling coupled 
to spring long-term hydrochemical monitoring: example of the La Clapière landslide (Southern Alps, France), Journal of Hydrology, in press, 2004.

Caris, J. P. T. and Van Asch, Th. W. J.: Geophysical, geotechnical and hydrological investigations of a small landslide in the French Alps, Engineering Geology, 31, 249-276, 1991.

Corominas, J.: New technologies for landslide hazard assessment and management in Europe. EC-Programme NEWTECH ENVCT96-0248, European Commission, Brussels, 1998.

De Marsily, G.: Quantitative Hydrogeology; Groundwater Hydrology for Engineers, Academic Press, London, 1986.

Farrel, D. and Larson, W.: Modelling the pore structure of porous media, Water Resources Research, 3, 699-705, 1972.

Flageollet, J.-C., Malet, J.-P., Schmutz, M., and Maquaire, O.: Integrated investigations on landslides: example of the SuperSauze earthflow, in Natural Disaster and Sustainable Development, edited by Casale and Margottini, Springer, Heidelberg, 2004.

Freeze, R. A. and Cherry, J. A.: Groundwater, Prentice-Hill, Englewood Cliffs, 1979.

Haneberg, W. C.: Pore pressure diffusion and the hydrologic response of nearly saturated, thin landslide deposits to rainfall, Journal of Geology, 99, 8, 886-892, 1991.

Hodge, R. A. L. and Freeze, R. A.: Groundwater flow systems and slope stability, Canadian Geotechnical Journal, 14, 466-476, 1977.

Iverson, R. M. and Major, J. J.: Groundwater seepage vectors and the potential for hillslope failure and debris flow mobilization, Water Resources Research, 22, 1543-1548, 1986.

Iverson, R. M.: Landslide triggering by rain infiltration, Water Resources Research, 36, 7, 1897-1910, 2000.

Iverson, R. M.: Sensitivity of stability analyses to groundwater data, in Proc. of the $6^{\text {th }}$ International Symposium on Landslides, edited by Bell, Christchurch, 451-457, 1992.

Keefer, D. K. and Johnson, A. M.: Earthflows morphology, mobilization and movement, U.S. Geological Survey Professional Paper, 1264, 1983.

Malet, J.-P., Maquaire, O., and Calais, E.: The use of Global Positioning System for the continuous monitoring of landslides, Application to the Super-Sauze earthflow (Alpes-deHaute-Provence, France), Geomorphology, 43, 33-54, 2002.

Malet, J.-P., Auzet, A.-V., Maquaire, O., Ambroise, B., Descroix, L., Esteves, M., Vandervaere, J.-P., and Truchet, E.: Soil surface characteristics influence on infiltration in black marls: application to the Super-Sauze earthflow (southern Alps, France), Earth Surface Processes and Landforms, 28, 5, 547-564, 2003.

Malet, J.-P., Maquaire,O., Locat, J., and Remaître, A.: Assessing debris flow hazards associated with slow moving landslides: methodology and numerical analyses, Landslides, 1, 1, 83-90, 2004.

Malet, J.-P.: Les glissements de type écoulement dans les marnes noires des Alpes du Sud. Morphologie, fonctionnement et modélisation hydro-mécanique, $\mathrm{PhD}$ Thesis, University Louis Pasteur, Strasbourg, 2003.

Malet, J.-P. and Maquaire, O.: Black marl earthflows mobility and long-term seasonal dynamic in southeastern France), in Proc. International Conference on Fast Slope Movements Prediction and Prevention for Risk Mitigation, Napoli, edited by Picarelli, 2003.

Maquaire, O., Flageollet, J.-C., Malet, J.-P., Schmutz, M., Weber, D., Klotz, S., Albouy, Y., Descloîtres, M., Dietrich, M., Guérin, R., and Schott, J.-J.: Une approche multidisciplinaire pour la connaissance d'un glissement-coulée dans les marnes noires (Super-Sauze, Alpes-de-Haute-Provence, France), Revue Française de Géotechnique, 95/96, 15-31, 2001.

Maquaire, O., Malet, J.-P., Remaître, A., Locat, J., Klotz, S., and Guillon, J.: Instability conditions of marly hillslopes, towards landsliding or gullying? The case of the Barcelonnette basin, South East France, Engineering Geology, 70, 1-2, 109-130, 2003.

Marquardt, D. W.: An algorithm for least-squares estimation of non-linear parameters, Journal of the Society for Industrial and Applied Mathematics, 11, 431-441, 1963.

Martinec, J., Rango, A., and Roberts, R.: The snowmelt runoff model (SRM). Version 3.2. Users Manual, University of Bern, 1994.

Miller, D. J. and Sias, J.: Deciphering large landslides: linking hydrological groundwater and stability models through GIS, Hydrological Processes, 12, 923-941, 1998.

Millington, R. J. and Quirk, J. P.: Permeability of porous solids, Transactions of the Faraday Society, 57, 1200-1207, 1961.

Montgomery, D. R. and Dietrich, W. E.: A physically-based model for the topographic control on shallow landsliding, Water Resources Research, 30, 4, 1153-1171, 1994.

$\mathrm{Ng}, \mathrm{C} . \mathrm{W}$. W. and Shi, Q.: A numerical investigation of the stability of unsaturated soil slopes subjected to transient seepage, Computers and Geotechnics, 22, 1, 1-28, 1998.

Parameter Estimation Inc.: Model-Independent Parameter Estimation. PEST Manual, Parameter Estimation Inc, Sandy, 1999.

Ridolfi, L., D'Odorico, P., Porporato, A., and Rodriguez-Iturbe, I.: Stochastic soil moisture dynamics along a hillslope, Journal of Hydrology, 272, 1-4, 264-275, 2003.

Reid, M. E., Nielsen, H. P., and Dreiss, S. J.: Hydrologic factors triggering a shallow hillslope failure. Bulletin of the Association of Engineering Geologists, 25, 3, 349-361, 1988.

Schmutz, M., Albouy, Y., Guérin, R., Maquaire, O., Vassal, J., Descloîtres, M., and Schott, J.-J.: Contribution of electrical and TDEM methods employed separately and combined to Super Sauze flowslide knowledge, Surveys in Geophysics, 21, 371390, 2000.

Théis, C. V.: The effect of a well on the flow of a nearby stream, AGU Transactions, 22, 3, 734-738, 1941.

Van Asch, Th. W. J. and Buma, J.: Modelling groundwater fluctuations and the frequency of movement of a landslide in the Terres Noires region of Barcelonnette, France, Earth Surface Processes and Landforms, 22, 131-141, 1997.

Van Asch, Th. W. J., Buma, J., and Van Beek, L. H.: A view on some hydrological triggering systems in landslides, Geomorphology, 30, 25-32, 1999.

Van Beek, L. H. and Van Asch, Th. W. J.: A combined conceptual model for the effects of fissure-induced infiltration on slope stability, in Process Modelling and Landform Evolution, edited by Hergarten and Neugebauer, 147-167, Springer, Berlin, 1999.

Van Beek, L. H.: The impact of land use and climatic change on slope stability in the Alcoy region, Spain, Netherlands Geographical Studies, Utrecht, 2002.

Weber, D. and Herrmann, A.: Reconstitution de l'évolution géomorphologique de versants instables par photogrammétrie numérique: l'exemple du glissement de terrain de Super-Sauze, Bulletin de la Société Géologique de France, 171, 6, 637-648, 2000.

Wesseling, C. G., Karssenberg, D., van Deursen, W. P. A., and Burrough, P. A.: Integrating dynamic environmental models in GIS: the development of a dynamic modelling language, Transactions in GIS, 1, 40-48, 1996. 